\title{
PLANNING, IMPLEMENTATION, AND EVALUATION OF THE SUBJECT OF PROFESSIONS IN THE GERMAN COURSES
}

\author{
HASAN COŞKUN \\ Çankırı Karatekin University, Faculty of Letters, \\ Department of Education, Fatih Mahallesi, \\ Uluyazı Kampüsü Ring Yolu, 18100 Çankırı, Turkey \\ E-mail: hcoskun1952@gmail.com \\ hasancoskun@karatekin.edu.tr \\ ORCID: 0000.0001-7673-8448
}

\begin{abstract}
Aim. In Turkey, in connection with the Bologna process, German is also taught in universities as an elective course. There is an important relationship between the selection of the subject in the elective German courses, detailed planning of the courses, and the implementation of the appropriate method. In this study, the subject of professions was planned for the elective German courses. The purpose of this study is the preparation, implementation, and evaluation of a sample lesson to describe the selection of the subject of professions for the German course taught as an elective course at universities.

Concept and Methods. This study was conducted with qualitative research. The document research technique was used in the study (Yildırım \& Şimşek, 2008). During the 2018/2019 academic year, I taught about the subject of profession selection in my German courses. I prepared, implemented and evaluated the subject of professions according to the lesson planning model I had previously developed (Coşkun, 2018). I prepared the materials used in this course according to this model.

Result and Conclusion. The success of the lesson planning model mentioned above was also observed in the activities conducted earlier. It was also seen that the students who attended German courses in connection with the Bologna process exerted efforts in establishing contact with the instructor and the students attending the class. It was observed that the participants introduced themselves, mentioned the field or the branch at the university where they were studying, and were interested in gaining experience abroad in order to be successful in their professions. In addition to the subject discussed in the class, the method implemented in the lesson and the planning of the lesson according to the method, play an important role in the continuation of this interest. Therefore, effective lesson planning models and unique methods should be developed.

Origin. Students from all the departments of the university may attend the elective German language classes opened in connection with the Bologna process. The condition for participation in the courses "German for Erasmus" and "German for Communication" which I teach, is to learn German at the A1 level. It is frequently observed that the participants speak German at different levels. The overseas experience of the participants, the quality of the German and other language education
\end{abstract}


they had received from primary to high school and university play an important role in this. In recent years the number of participants from German and other foreign language speaking countries has increased. The students who had been in German-speaking countries under the Erasmus program participate in the German courses also to maintain their fluency in the German language. In order to execute the German courses effectively for different purposes, for different fields and participants coming from different countries and students with different levels of fluency, a suitable method should be developed. It is believed that this inter-disciplinary study will contribute to the active German courses.

Key words: vocational training, profession, study, German language teaching, lesson planning

\section{INTRODUCTION}

Tt is presumed that initially, the desire to establish contact with persons spelaking different languages leads to learning a foreign language (Hengirmen, 2006). At first, the translation method was used in learning a foreign language. In time, different methods were developed in learning a foreign language. Today, communication methods are recommended (Roche, 2005). Developments in the fields of science, art, education, employment, law, tourism, and trade have increased the importance of learning a foreign language. Especially, the globalization process has increased the interest in foreign languages even more. The youths in Turkey, where unemployment is high, are affected by these developments. First of all, being multi-lingual increases the employment opportunities of the individual. Therefore, families in Turkey are exerting efforts so that their children can learn more than one foreign language at an early age.

The desire to become a member of the European Union plays an important role in the learning of a foreign language in Turkey. As we know, in the European Union it is encouraged to teach at least two foreign languages in the curriculum of the countries which are members of the European Union or which aspire to become members. Therefore, the Ministry of Education is carefully monitoring the innovations in the field of communication, on the interaction between the cultures and the developments in the world (Coşkun, 2013).

Especially the private educational institutions in Turkey are advertising that they are teaching more than one foreign language to attract more attention. In some of the districts of the megacities such as Istanbul, Ankara, and Izmir, teaching a foreign language has become a routine curriculum in some primary schools. Because the high schools in Anatolia are teaching two foreign languages in their curriculum, the classical high schools have been converted into Anatolian high schools. To enable the students to benefit from multiple languages, the Imam Hatip high schools, which emphasize religious teaching, are using the name of Anatolian high school. The students attending the Anatolia Imam Hatip high schools, are taught English and German in addition to Arabic and Ottoman languages. Measures are being taken to give French, Russian, Spanish, Japanese, Italian and Arabic courses in addition to English and German. 
As stated above, in Turkey generally English is elected as the first foreign language. German and other languages are elected as a second foreign language. It is observed that in addition to the classic foreign languages, interest has increased in foreign languages such as Russian, Korean, and Japanese spoken in the Far Eastern countries.

It is also observed that different measures are being taken in Turkey to be successful in learning a foreign language. Institutionally, translations are made from English, German and French (Kocaman, 2014; Kocaman, 2018; Viau, 2009, translation by Budak, 2015) and the educational institutes are being equipped with new Technologies (Öz, 2014,). Because the majority of the teachers in most cases have not received sufficient training in active language education and the lack of physical capabilities in the educational institutions, it is not easy to implement the knowledge gained institutionally.

In spite of all of these efforts, it is asserted that Turkey is not successful in teaching a foreign language (Bayraktaroğlu, 2014). Generally, crowded classrooms, classical training of teachers, outdated textbooks, lack of additional materials, and the use of grammar method in teaching are usually cited as reasons for this. Obviously, there are a number of recommendations in the manuals to be successful in teaching a foreign language (Hölscher, et al. 2006; Roche, 2005; Brandhofer-Bryan, 2008). According to my experience, the most important method of teaching is the selection of the subjects that directly interest the students and planning the lesson in a detailed manner, development, implementation of the education materials and evaluation of the same in order to activate teaching. It is believed that a lesson given in this framework will increase the motivation of students.

One of the most current subjects in Turkey is education for the profession, as is the case worldwide. The former Minister of Education in Turkey, Ömer Dinçer (2012) emphasized that one of the most important problems in Turkey are professional and technical training. Because the employment of youth is one of the most important subjects. The 10/2017 issue of the Erziehung \& Wissenschaft magazine dedicated the 10/2017 issue of its magazine to professional training. In this issue, Professional education was explained in detail. It is also observed that the issue of professional education has been included in the textbooks (Koithan, Schgmitz, Sieber \& Sonntag, 2014). The Federal Employment Agency [Bunsdesagentur für Arbeit] (2018) has published a comprehensive encyclopedia on the current professions. The subject of professions is also mentioned in the books published for learning German. The Czech Republic has published a unique book to teach German in respect to professional education (Glowacka-Perlowska, 2007).

Especially in the last decade, the demand for qualified personnel has increased owing to the stability in the German economy. Collaterally, the number of foreign youths who want to work and live in Germany increases day by day. This development has raised the interest of foreigners in learning German.

It is observed that this development has affected university students also in Turkey. The university students are aware that English is the universal langu- 
age. Because of the lack of employment opportunities in Turkey, the students show great interest in German courses. Obviously, this situation leads to intellectual migration. We will not discuss intellectual migration here. In this study, I have prepared a sample lesson plan for the German courses on the subject of profession selection. It is possible to use this sample plan in other languages as well. I have discussed the subject of professions in the German courses I gave during the academic year 2018/2019.

\section{METHOD}

This study was conducted with the employment of the qualitative method (Yıldırım \& Şimşek, 2008). I initially developed a draft for class preparation in collaboration with the experts. In the study, literature related to language teaching and the documents I prepared, were used. Additionally, I benefited from the discussions I held with the experts and the students. In my previous studies, I had identified 24 widely preferred professions (Coşkun, 2006). In the lesson, actual words in addition to these words were used.

Discussions were held on the changes made in the professions over time. In the lesson on the introduction to pedagogy, which I give in Turkish, the students participating from the drawing and graphics branch of the Faculty of Arts, prepared visuals (drawings) for the key word and renewed the drawings related to 24 professions. A drawing was designed for the key word. In this drawing 5 short sentences in Turkish, German and English were written for the 24 words and a drawing. It comprised of two pages and was prepared in three languages. With respect to these studies, the contents of the books used in the courses were also updated (Coşkun \& Deveci, 2006).

These educational materials were applied in two universities to 120 students in groups of four. 80 students in the faculty of pedagogy were studying to become English teachers. These students were also taking German as a second language. The other 40 students were from different faculties and wanted to go to countries where German is, under the Erasmus program. Generally, the German language fluency of the students was at A1 and A2 level. The students living in Germany assumed tutorship for a certain period of time. The changes found necessary to be made in the educational materials used were made in the light of the experience gained during the four week teaching period. The preparation, application, and evaluation of this sample lesson plan was based on the 13 step - daily lesson planning model which was developed by me previously (Coşkun, 2018).

\section{GENERAL INFORMATION}

The sample lesson plan should be aimed at a specific target group. Therefore, general information such as the education institution, branch of the lesson, the subject, and the duration should be identified. The prepared sample 
lesson plan should be aimed at a target group. Therefore, the type of school, the name of the lesson, the subject, and the duration should be stated.

In Turkey, students have the opportunity to learn foreign languages in primary schools, secondary schools, high schools, and universities. It is observed that pre-school institutions also emphasize the importance of learning a foreign language. The most frequently selected foreign languages are English, German, French, Russian, Chinese, Spanish, Arabic, and Japanese. It is also observed that important is being placed on the teaching of the Ottoman language, which comprises of Turkish, Persian and Arabic. As Turkey is a candidate for European Union membership, two foreign languages are taught in schools. In general, English is elected as the first foreign language and German as the second in educational institutions.

It is asserted that Turkey is not successful in teaching foreign languages in spite of all these efforts. Generally, the reasons for the lack of success is the fact that the classes are crowded, teachers are taught with the classical method of teaching, the lesson textbooks are not up to date, lack of additional materials and utilization of grammar-oriented methods. Obviously, there are a number of recommendations in the guide books to be successful in the teaching of a foreign language. According to experience, the best method is the selection of current subjects which directly interest the students and the planning of the lesson material in a detailed manner, development, application of the lesson materials, and to evaluate them according to active learning. As is the case throughout the world, one of the most current subjects is professional education. Youth's unemployment is one of the most important problems.

It is observed that this issue is also reflected in textbooks. In the books published for German courses, this subject is contained therein. Especially in the next decade, there is a need for qualified personnel in Germany thanks to the stability of the German economy. The number of foreign youths who want to live and work in Germany is growing daily. This development and this aspiration led to learning the German language. These effects are also visible in the university students of Turkey. The university students are aware that English is a universal language. Because of the employment opportunities, the university students in Turkey are showing great interest in the German courses. In this study, a sample lesson plan on professions was prepared for the German course. The sample lesson plan contained herein may be used for courses in other foreign languages. The subjects of professions were used in the elective German language courses I gave during the 2018/2019 academic year.

As stated in the method section the subject of professions was discussed in two universities with 120 students in 4 groups. Obviously, among the four groups, there were differences in the fluency of German and the level of motivation. Because those students studying to become English teachers were taking German as a mandatory elective course and the other students attending the German courses opened by the president of the university were attending the courses to study Germany for a specific period of time and/or to work in Germany. To the extent possible, these differences were taken into consideration in 
the planning, implementation, and evaluation of the lesson, and in developing the teaching materials.

\begin{tabular}{cc}
\hline Target Group : & $\begin{array}{c}\text { Students attending the elective German courses in the } \\
\text { university }\end{array}$ \\
\hline Name of the lesson: & Elective German course \\
\hline Subject of the lesson: & Professions \\
\hline Duration of the lesson: & 80 minutes (2 lecture hours \\
\hline
\end{tabular}

\section{RATIONALE OF THE LESSON}

One of the purposes of the Turkish national education is to provide a profession for the individuals (Ministry of National Education, 2010). Teaching a profession increases the possibilities of employment in Turkey on one hand and the possibilities of employment abroad on the other. For example, Germany is supporting the project on professional training in Turkey in order to benefit from the young population in Turkey (Aykır, 2018). Companies such as Bosch, MAN, and Mercedes situated in Turkey place great importance on the professional training units. Effective steps should be taken in Turkey on professional training.

In Turkish education system, it is observed that in general, an acceptable balance between the academic and professional education has not been established. It is also observed that this balance has not been established in the birth ratio, industrialization, and in the field of employment. Rates of unemployment, especially among the young generation, are very high. As the rate of employment increases among young people who have received a general academic education, the importance of professional education becomes emphasized. It is assumed that more importance will be placed on professional education in the coming years. Therefore, importance should be placed on the young generation learning a valid profession.

Two subjects surface in this study. should be enumerated. First is that the students learn a profession; the second is that the students learn one or two foreign languages. There are various reasons for learning a foreign language:

- To continue their education abroad and to work

- To work in a foreign company situated in Turkey

Professional training in Turkey has gained a new dimension owing to immigration. It is estimated that there are more than 4-5 million immigrants living in Turkey. For the immigrants to be employed within a short period of time the qualifications they had gained in their country should be considered, and assistance should be provided for those who do not have any profession. It is possible to benefit from Germany's experiences in this regard. It is observed that in addition to professional training in general, this subject is also included in the language training books. Here, we will discuss the 3 studies. 
Yılmaz's (2011) book "Mein Sprach- und Deutschlandbegleiter" [My language and Germany companion] published in German and Turkish is an important source. This book supports social harmony. This work was later translated into Arabic. This work covers daily life subjects.

This book also contains the necessary skills and phrases for the people of Turkish origin to express themselves and to effectively participate in daily life. This book also contains a dictionary in two languages in various fields and subjects. It contains a word list of two pages for school and professional training. One of the subjects prepared in detail is the subject of health. Those working in the field of language teaching may also benefit from this book.

The purpose of the book "Technisches Deutsch für Ausbildung und Beruf, Lehr- und Arbeitabuch" [Technical German for Education and Profession, Textbook and Workbook] written by Rosemarie Fearns and Anneliese Buhlmann (2013) is to contribute in the gaining qualified workers for the German economy. The metal and electronic industry which houses approximately 70 professions and which is the key branch of the German economy requires young and qualified workers. The mentioned book says that the requirement for qualified personnel may primarily be met by young immigrants. Additionally, the book states that only professional knowledge and skills will not be sufficient for innovation and stresses the fact that the individual should have initiative and put his thoughts into action. This book comprises the following sections:

1. Information on how to use the book.

2. Read, hear, speak and write in technological communication.

3. Manufacturing engineering

4. Materials Technology

5. Fundamentals of Electrical Engineering I

6. Fundamentals of Electrical Engineering II

7. Studying and working in Germany

They have divided the Works of Gernot Häublein and Recs Jenkins (2018) into subjects. One of the subjects is "Berufs- und Arbeitswelt" [Professional and working World]. This section contains some important words both in English and German. Instructors who give German courses may take advantage from the sources mentioned above or similar sources, have the opportunity to plan, implement, and evaluate according to the Common European Framework of Reference for Languages (GER).

\section{THE OBJECTIVES OF THE LESSON}

The objective is the desired characteristics we want the individual to possess that could be acquired through education. The goals are separated into three: long-term goals, general objectives/general goals, and fine goals. These goal 
groups must be consistent with one another. In application fine goals are referred to as goals only. Long term goals are related to general education, general goals are related to educational institutions, and fine goals are related to the envisioned courses. Therefore, fine goals are those habits such as knowledge, skill, talent, interest, thrift, and habits. These features are divided into three fields such as cognitive, emotional and psychomotor. Fine objectives shed light on learning experiences, the methods and techniques to be applied in the lesson and on measuring and evaluation activities (Bilen, 1993). The objectives intended to be achieved in the professions listed below were formulated.

The students who take part in this lesson will:

- Try to remember what they have learned with respect to professions

- Know the names of 24 current professions

- They can describe the professions of their family members when they introduce themselves.

- They know the branch they are studying in and can say in what profession they want to work in the future.

- They understand the importance of professional training.

- They understand a simple conversation dealing with their profession.

- They understand a simple text related to their professions.

- They can write simple text related to their profession.

\section{EXPLANTATION OF THE KEYWORD AND THE 24 WORDS USED IN THE LESSON}

The importance of communication has increased with globalization. It is also being promoted in Turkey that students learn at least two foreign languages. Therefore, it is important that students come into contact with foreign languages.

I have designed all the works that I have performed up to now on teaching a foreign language based on the Nine Stone Game (Coşkun, 2006). One keyword and 24 words are used in this unique game I have prepared to teach the subject and practice pages. The keyword should symbolize the subject selected and the 24 words should be directly related to the subject. Words should be easy to understand so that some pictures can be drawn from them. The meaning of the keyword should also be written in German and English.

The selected 24 words should be placed in alphabetical order in the language the target groups know best. Then, the corresponding words of the other languages should be written in the tri-lingual list.

It is possible to increase the number of languages in the word list of the composition of the target group accordingly, in other words, according to their requirements. The word lists I use include at least three languages. The chart prepared for the key word calls for five sentences written in Turkish, German, and English for the said drawing. After the key word, the given tri-lingual list is inserted. In the later stage, it is recommended for the students to write 
sentences with the words contained in the list and then to write texts from the sentences.

Table 1. Flashcard for professions.

The key word and the 24 words used in the lesson

Flaś Kart / Lernkarte/ Flash Card die Berufe

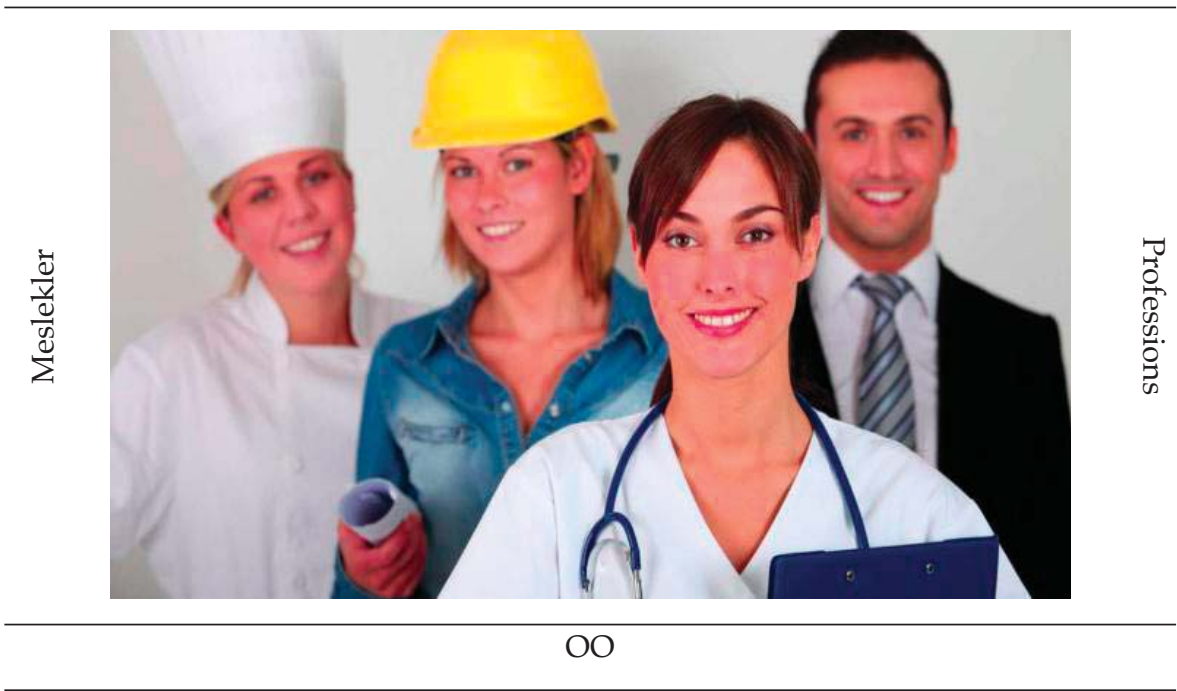

Bu resim ile ilgili 5 Türkçe, Almanca ve İngilizce cümle yazınız.

Schreiben Sie über dieses Bild 5 Sätze auf Türkisch, Deutsch und Englisch.

Write down 5 sentences about this picture in Turkish, German and English.

\begin{tabular}{llll}
\hline No & \multicolumn{1}{c}{ Türkçe } & \multicolumn{1}{c}{ Deutsch } & \multicolumn{1}{c}{ English } \\
\hline 01 & $\begin{array}{l}\text { Bir meslek öğrenmek } \\
\text { önemlidir. }\end{array}$ & $\begin{array}{l}\text { Es ist wichtig, einen } \\
\text { Beruf zu erlernen. }\end{array}$ & $\begin{array}{l}\text { It is important to learn a } \\
\text { profession. }\end{array}$ \\
\hline 02 & $\begin{array}{l}\text { Meslek okulda ve bir } \\
\text { firmada öğrenilir. }\end{array}$ & $\begin{array}{l}\text { Der Beruf wird in der } \\
\text { Schule und in einer } \\
\text { Firma gelernt. }\end{array}$ & $\begin{array}{l}\text { A profession is learned at } \\
\text { school and in a company. }\end{array}$ \\
\hline 03 & $\begin{array}{l}\text { Meslek seçiminde } \\
\text { bir danı̧̧̧än ile } \\
\text { görüşünüz. }\end{array}$ & $\begin{array}{l}\text { Besuchen Sie bei der } \\
\text { Berufswahl einen } \\
\text { Berater. }\end{array}$ & $\begin{array}{l}\text { Visit a consultant when } \\
\text { choosing a career. }\end{array}$ \\
\hline 04 & $\begin{array}{l}\text { Geçerli bir meslek ve } \\
\text { yabancı dil istihdam } \\
\text { olanaklarını arttırır. }\end{array}$ & $\begin{array}{l}\text { Ein guter Beruf und eine } \\
\text { Fremdsprache erhöhen } \\
\text { die Einstellungs- } \\
\text { möglichkeiten. }\end{array}$ & $\begin{array}{l}\text { A good job and a foreign } \\
\text { language increase the } \\
\text { employment options. }\end{array}$ \\
\hline 05 & $\begin{array}{l}\text { Güncel bilgi için } \\
\text { hizmet içi eğitim } \\
\text { kursları önemlidir. }\end{array}$ & $\begin{array}{l}\text { Fortbildungskurse } \\
\text { sind für aktuelle } \\
\text { Informationen wichtig. }\end{array}$ & $\begin{array}{l}\text { In-service training courses } \\
\text { are important for up-to-date } \\
\text { information. }\end{array}$ \\
\hline
\end{tabular}


Table 2. The first group of words for professions.

\begin{tabular}{|c|c|c|c|c|}
\hline Nr. & Bild & Türkisch & Deutsch & English \\
\hline 01 & & asker & der Soldat & soldier \\
\hline 02 & & bahçıvan & der Gärtner & gardener \\
\hline 03 & & $\begin{array}{l}\text { banker } \\
\text { Bankacı }\end{array}$ & $\begin{array}{c}\text { der Bankier } \\
\text { der Bankkauf- } \\
\text { mann }\end{array}$ & $\begin{array}{c}\text { banker } \\
\text { bank employee }\end{array}$ \\
\hline 04 & & çöpçü & der Müllmann & garbage man \\
\hline 05 & & doktor & der Doktor & doctor \\
\hline 06 & & fotoğrafçı & der Fotograf & photographer \\
\hline 07 & & futbolcu & $\begin{array}{c}\text { der } \\
\text { Fußballspieler }\end{array}$ & football player \\
\hline 08 & & garson & der Kellner & waiter \\
\hline 09 & & hemşire & $\begin{array}{c}\text { die Kranken- } \\
\text { schwester }\end{array}$ & nurse \\
\hline 10 & & heykeltıraş & der Bildhauer & sculptor \\
\hline 11 & & inşaat işçisi & der Bauarbeiter & $\begin{array}{l}\text { construction } \\
\text { worker }\end{array}$ \\
\hline
\end{tabular}




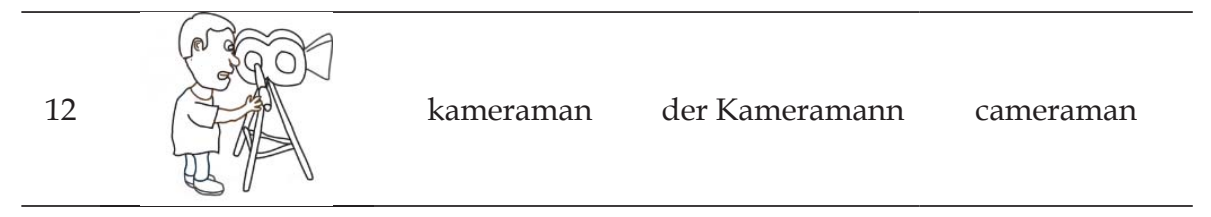

Table 3. The second group of words for professions.

Sözcük Listesi / Wortliste / Word List / Meslekler / Berufe / Professions (b)

\begin{tabular}{|c|c|c|c|c|}
\hline Nr. & Bild & Türkisch & Deutsch & English \\
\hline 13 & & kaptan & der Kapitän & captain \\
\hline 14 & & marangoz & $\begin{array}{c}\text { der Tischler } \\
\text { der Zimmermann }\end{array}$ & carpenter \\
\hline 15 & & mimar & der Architekt & architect \\
\hline 16 & & mühendis & der Ingenieur & engineer \\
\hline 17 & & müzisyen & der Musiker & musician \\
\hline 18 & & öğretmen & der Lehrer & teacher \\
\hline 19 & & pilot & der Pilot & pilot \\
\hline 20 & & ressam & der Maler & painter \\
\hline 21 & & sekreter & die Sekretärin & secretary \\
\hline
\end{tabular}




\begin{tabular}{|c|c|c|c|}
\hline 22 & şoför & der Fahrer & driver \\
\hline 23 & tamirci & der Mechaniker & repairman \\
\hline 24 & terzi & der Schneider & tailor \\
\hline
\end{tabular}

\section{A DiALOGUE}

In this lesson preparation model, a dialogue is written for each lesson. Apart from the teacher here 6 people participate in this dialogue. The dialogue contains the key word and 24 words in the subject area.

\section{PROFESSIONS}

\begin{tabular}{|c|c|}
\hline Teacher & $\begin{array}{l}\text { The Schneider family has two children. Their son has graduated } \\
\text { from secondary school and their daughter has graduated from } \\
\text { high school. } \\
\text { They would like to get advice for apprenticeship and academic } \\
\text { studying. } \\
\text { That's why the Schneider family is in the employment agency. }\end{array}$ \\
\hline Task & $\begin{array}{l}\text { Form six - person groups and arrange the conversation as } \\
\text { roleplaying in the presence of the class. }\end{array}$ \\
\hline $\begin{array}{l}\text { Role distribution } \\
\text { (Participants) }\end{array}$ & $\begin{array}{l}\text { 1. Father (Bernd), 2. Mother (Jutta), 3. Daughter (Helin), 4. Son } \\
\text { (Kerim), 5. Consultant (Holger) und 6. Girlfriend (Derin) }\end{array}$ \\
\hline \multicolumn{2}{|l|}{ Part 1} \\
\hline 01 Father & $\begin{array}{l}\text { It is 9:00 clock. We will go to the employment agency } \\
\text { together. }\end{array}$ \\
\hline 02 Mother & $\begin{array}{l}\text { You're right. Our children have a secondary school diploma } \\
\text { and a high school diploma. }\end{array}$ \\
\hline Son & $\begin{array}{l}\text { I have a secondary school diploma with a good average } \\
\text { grade. } \\
\text { I want to learn a profession. I really want to be a gardener. }\end{array}$ \\
\hline Daughter & $\begin{array}{l}\text { I have a high school diploma with a good average. I want to } \\
\text { study medicine. I want to } 1 \text { be a good doctor. As a doctor of } \\
\text { medicine you have a good status. }\end{array}$ \\
\hline Mother & The best way is to consult an Employment Agency. \\
\hline
\end{tabular}




\begin{tabular}{|c|c|c|}
\hline & Father & Get in the car. We're going there right away. \\
\hline 07 & Consultant & Welcome! My name is Meier. How can I help you? \\
\hline 08 & Daughter & $\begin{array}{l}\text { I have a high school diploma and my brother has a secondary } \\
\text { school diploma. We would like to get some advice. }\end{array}$ \\
\hline 09 & Father & $\begin{array}{l}\text { Our son can become a professional soldier. As a soldier he } \\
\text { can defend our country and fight for peace. }\end{array}$ \\
\hline 10 & Girlfriend & $\begin{array}{l}\text { My friend Kerim would be a good photographer or waiter. } \\
\text { As a musician or captain he would be good. I love uniforms. }\end{array}$ \\
\hline \multicolumn{3}{|c|}{ Part 2} \\
\hline 11 & Consultant & $\begin{array}{l}\text { Photographer and musicians are good professions, but } \\
\text { there is a lot of competition and job opportunities are very } \\
\text { limited. Even a captain is not so easy today. Waiters are } \\
\text { sought everywhere today. My friend Kerim would be a good } \\
\text { photographer or waiter. }\end{array}$ \\
\hline 12 & Mother & $\begin{array}{l}\text { Our daughter could work as a nurse before studying } \\
\text { medicine if she does not get a place in the next semester. }\end{array}$ \\
\hline 13 & Daughter & I did not think about the job of a nurse at all. \\
\hline 14 & Father & Could our son be successful as a football player? \\
\hline 15 & Son & Maybe I could do some training as a construction worker first. \\
\hline 16 & Daughter & $\begin{array}{l}\text { That's a good idea. Later, you can catch up on high school, } \\
\text { study and become an engineer or architect. }\end{array}$ \\
\hline 17 & Mother & $\begin{array}{l}\text { Would you recommend an apprenticeship as a sculptor or } \\
\text { cameraman? }\end{array}$ \\
\hline 18 & Girlfriend & I know that Kerim is also interested in art. \\
\hline 19 & Consultant & $\begin{array}{l}\text { Instead of a sculptor or cameraman, I would like to } \\
\text { recommend training as a professional driver. Drivers are } \\
\text { always wanted. What do you think about it? }\end{array}$ \\
\hline 20 & Son & $\begin{array}{l}\text { If I receive a technical education, I could also work } \\
\text { successfully as a mechanic. }\end{array}$ \\
\hline \multicolumn{3}{|c|}{ Part 3} \\
\hline 21 & Daughter & How about a secretary at a medical school (faculty)? \\
\hline 22 & Consultant & $\begin{array}{l}\text { Do you want to receive professional education at a bank? } \\
\text { You can work there later as a customer advisor. Maybe later } \\
\text { you may become a bank manager. }\end{array}$ \\
\hline 23 & Son & $\begin{array}{l}\text { I would like to go on holiday next year. I need money for } \\
\text { that. For example, I want to work as a garbage man in the city } \\
\text { municipality. }\end{array}$ \\
\hline 24 & Girlfriend & $\begin{array}{l}\text { Kerim can do an apprenticeship as a carpenter He will then } \\
\text { make tables, cabinets, windows and doors. }\end{array}$ \\
\hline 25 & Father & $\begin{array}{l}\text { He can graduate from the public education center and study } \\
\text { in woodworking. As an engineer, he will earn well. }\end{array}$ \\
\hline 26 & Consultant & $\begin{array}{l}\text { As an engineer, he will also be able to find a good job abroad. } \\
\text { Canada is looking for engineers. }\end{array}$ \\
\hline 27 & Daughter & $\begin{array}{l}\text { At present, teachers are being sought in Germany. I would } \\
\text { like to work as a teacher and engage in inclusion for schools. }\end{array}$ \\
\hline
\end{tabular}




\begin{tabular}{lll}
\hline 28 Mother & I would like to recommend our son to be trained as a pilot. \\
\hline 29 Son & $\begin{array}{l}\text { Now and then I think of art. A Painter or fashion designer } \\
\text { would be my dream. }\end{array}$ \\
\hline & $\begin{array}{l}\text { Mr. Meier, it is not easy to decide on an apprenticeship } \\
\text { or a degree. May we take the book „Beruf Aktuell of } \\
\text { Bundesagentur für Arbeit” [Occupation Current of Federal } \\
\text { Employment Agency] (2018). At home we shall continue } \\
\text { talking. Thanks a lot for your help. }\end{array}$ \\
\hline
\end{tabular}

Questions related to the dialogue

1. What are the participants in the conversation called?

2. What qualifications do the children of the Schneider family have?

3. Which professions does the son think about in part 1 ?

4. What does the daughter say in part 2 about the profession of nurse?

5. What profession does the advisor in Part 3 suggest to the son?

\section{READING TEXT}

In my model, writing a text, comprised of approximately 200 words and 5 paragraphs on the subject envisioned is requested. In the text attention should be paid to use the keyword and the 24 words contained in the tri-lingual list in a balanced manner.

\section{PROFESSIONS}

In this lesson preparation model, a reading text of approximately 200 words is written. The reading text consists of five paragraphs. In this reading text, the keyword and the 24 words about the subject of professions are used.

1. A recognized profession or study of a subject with a future is important in Germany for young people. German families give great importance to it. That is also desired by the companies. Young people learn a profession such as a secretary, carpenter, and mechanic in a vocational school and in a company. You become a doctor, an engineer, and an architect by studying at a university.

2. There are young people who are interested in art. They work as a photographer, sculptor or musician. The painter profession is very common. As a cameraman, you have a versatile job. You work for a TV station, in the parliament or in war zones. Nurses are also in demand in Germany. Germany has been recruiting nurses even from the Far East for several years now. Male nurses are also sought because people in Germany are getting older and older. Currently, there are construction workers or craftsmen such as tailors and carpenters from Poland or Bulgaria.

3. Occupations in the hotel and hospitality industry offer young people good career opportunities. They often start as waiters. Then they study in the 
field of gastronomy or hotel business. Anyone who learns a job gets a wage from the company. Anyone who studies may receive BAföG (The Federal Training Promotion Act), depending on the income of the parents. After completing your studies, half of the funding or a maximum of $€$ 10,000 must be repaid to the state. Foreign high school graduates with very good diplomas or very good students with excellent knowledge of German can get a scholarship from various German foundations or from the DAAD. This may be for a full or partial study.

4. Many young people also decide their professions as a soldier, gardener or banker. The profession of a soldier is important for ensuring security and peace. The gardener is interested in the aesthetics of the environment. Every city needs reliable banks. The banker regulates finance. As a rule, the garbage man collects garbage. This is an important service. At the moment you can easily find a job as a teacher. It is important that the teacher speaks English and the language of migrants.

5. One of the most popular sports is football. The famous German Toni Schumacher was also a successful goalkeeper in Turkey. The Turkish-born football player Mesut Özil played for a long time in the German national team. Germany has reliable airlines. Lufthansa Airlines is famous worldwide. As a pilot you could work at Lufthansa. Shipping is an important sector for the economy in Germany. As a captain, you are often traveling by ship for days. As a driver of buses or train driver, you have an important job. It is crucial that buses and trains are on time. Depending on the degree, every young person in Germany has the opportunity to study and/or study a profession.

\section{Questions related to the reading text}

1. What is important for young people in Germany? (Clause / paragraph 1)

2. Why are nurses in Germany in demand (wanted)? (Clause / paragraph 2)

3. In which area do waiters study? (Clause / paragraph 3)

4. What is the profession of soldier important for? (Clause / paragraph 4)

5. Where was the famous German Toni Schumacher a successful goalkeeper?

\section{RULES OF THE EDUCATIONAL GAME ON PROFESSIONS}

In this lesson preparation model, the rules of the learning game are an important element. Therefore, the rules of the game in 30 items have been described for this lesson. Below are the rules.

\section{No Rules of the Educational Game on Professions}

01 The purpose of the game is to improve the language skills on professions and to accomplish this activity in an entertaining manner.

02 The participants are divided into groups of 5 persons. Four out of the five persons will be competitors and one of them will be the referee.

03 The four participants will be divided into sub-groups of two persons. 
04 In the composition of the groups of five, the remaining members will serve as assistants.

0525 cards each in the size of $8 \times 8 \times 0.5 \mathrm{~cm}$, written with the rules of the game and a salad sheet with two words, and 2 student sheets will be given.

06 One of the cards will contain the key words of the professions and the other 24 cards will be related to professions.

07 One surface of the keyword card will contain the symbols of the professions and the other surface will contain the number 00 together with the symbols of the professions in Turkish, German and English.

08 The front pages of the other 24 cards will bear the symbols of the professions in pictures and will be written in Turkish, German and English.

09 The referee will place the 25 cards in the center of the table with the symbols of the professions facing the front and pile up the cards in the shape of a tower in a mixed manner.

10 The sub-group which will begin the game shall be determined with the throw of a dice. The sub-group which gets the biggest number will be group A and the other will be group B.

11 At every move, a card will be taken from the top of the pile.

12 The A group which will begin the game shall say "we are beginning the game" / "Wir beginnen" / "We begin" and draw the first card from the top and say the number and picture of the card in Turkish.

13 Group B shall say the German and the English of the Turkish word.

14 If Group B says the Turkish word in German and English correctly, they will enter the German and the English words in the list prepared for the three languages and where the Turkish words are found.

15 Thereafter, Group B will prepare sentences in German and in English with the help of the salad page and place the card in one place. In order not to disrupt the flow of the game the sentences made will not be written in the list.

16 The referee shall determine if the words are pronounced properly and if the sentences made are correct or not.

17 If the decision of the referee is favorable the Group A will take a second card in the same manner. (If the decision of the referee is not favorable it will be Group B's turn).

18 If Group B does not know the German and the English of the word or does not make proper sentences in German and English, A group will place this card at the very bottom of the tower.,

19 Now, it is Group B's turn to take a card.

20 Group A will tell the Group B "sira sizde", / Ihr seid an der Reihe" / "It's your turn".

21 Group B will thank the Group A and say "Dankeschön" / Thank you".

22 Group A says "Rica ederim" / "Bitte schon" / You are welcome" and Group $B$ repeats what the Group A has done; takes the third card and reads the number and the Turkish version.

23 Group B waits for the Group A to say the German and English words of the 3rd card taken and to make the German and English sentences. 
24 If Group A says the German and the English words of the card taken and correctly makes the sentences, it will enter the words in the list. It will place the card aside and Group B continues to draw the card.

25 If Group A does not say the German and the English of the Word written in the card and cannot make proper sentences from these words it will place the card under the stack and Group A will continue to draw the card.

26 The game will continue in this manner until all the cards are drawn.

27 At the end of the activity the students will deliver all the cards to the referee and keep the leaves.

28 Both of the groups will share the words they have entered in the plenum and the sentences they had made with the other groups.

29 Group B waits for the Group A to say the German and English words of the 3rd card taken and to make the German and English sentences.

30 The participants will also thank the teacher.

Explanation: It is also possible to play Memory-Spiel/Memory Game by compiling the cards of the two groups. The rules of this version shall be determined by the players.

\section{THE MATERIALS TO BE USED FOR THE EDUCATIONAL GAME}

The use of unique materials plays an important role in courses. It is recommended that they use pictures (images), drawings, charts, etc. when necessary. Before beginning the educational game the teacher may show some pictures of professions with a projector on the wall and may ask for explanations of these images. Later, the teacher asks the students some questions in line with the questions outlined below. For this lesson, flash cards, in the size of $8 \times 8 \times 0.5$ $\mathrm{cm}$ cards, dialogue, reading a text, sentence salad, and exercise sheets were developed as material.

Table 4. The flow chart of the lesson

\begin{tabular}{|c|c|c|c|c|c|}
\hline Step & $\begin{array}{l}\text { Dura- } \\
\text { tion } \\
\text { (min.) }\end{array}$ & Teacher Behavior & Student Behavior & $\begin{array}{l}\text { Tech- } \\
\text { nique / } \\
\text { Method }\end{array}$ & $\begin{array}{c}\text { Materi- } \\
\text { als }\end{array}$ \\
\hline 01 & $4 \mathrm{~min}$. & $\begin{array}{l}\text { The teacher starts the } \\
\text { lesson with a brief } \\
\text { introduction and an- } \\
\text { nounces the subject of } \\
\text { professions. } \\
\text { He gives an example. } \\
\text { I am a teacher. And } \\
\text { you? }\end{array}$ & $\begin{array}{l}\text { The students introduce } \\
\text { themselves. Answer } \\
\text { the questions. } \\
\text { I am a student. } \\
\text { He is a student. } \\
\text { She is a student. } \\
\text { We are students. }\end{array}$ & $\begin{array}{l}\text { Ques- } \\
\text { tion } \\
\text { answer }\end{array}$ & \\
\hline
\end{tabular}




\begin{tabular}{|c|c|c|c|c|c|}
\hline 02 & $\begin{array}{c}6 \\
\text { min. }\end{array}$ & $\begin{array}{l}\text { The teacher shows im- } \\
\text { ages of different profes- } \\
\text { sions and asks what the } \\
\text { participants think about } \\
\text { the images. } \\
\text { The teacher asks: } \\
\text { What is your mother by } \\
\text { profession? } \\
\text { What is your father by } \\
\text { profession? }\end{array}$ & $\begin{array}{l}\text { The students discuss } \\
\text { the images reflected on } \\
\text { the wall. } \\
\text { The students answer: } \\
\text { My mother is a nurse. } \\
\text { My father is an archi- } \\
\text { tect. }\end{array}$ & $\begin{array}{l}\text { Oral } \\
\text { state- } \\
\text { ment }\end{array}$ & Images \\
\hline 03 & $\begin{array}{c}10 \\
\text { min. }\end{array}$ & $\begin{array}{l}\text { He asks the students to } \\
\text { hang the flash cards ac- } \\
\text { cording to the first sec- } \\
\text { tion of the instructions. } \\
\text { The teacher draws the } \\
\text { clothes line in the class- } \\
\text { room. He gives those } \\
\text { in the front line } 25 \text { flash } \\
\text { cards } 25 \text { clothespins } \\
\text { and clothesline instruc- } \\
\text { tions enough for groups } \\
\text { of two. }\end{array}$ & $\begin{array}{l}\text { The students hang } \\
\text { the flash cards on the } \\
\text { clothes line in groups } \\
\text { of two. } \\
\text { The students hang in } \\
\text { groups of two the flash } \\
\text { cards on the clothes- } \\
\text { line. }\end{array}$ & $\begin{array}{l}\text { Group } \\
\text { work }\end{array}$ & $\begin{array}{l}25 \text { flash } \\
\text { card, } \\
25\end{array}$ \\
\hline 04 & $\begin{array}{c}12 \\
\text { min. }\end{array}$ & $\begin{array}{l}\text { The teacher asks the } \\
\text { students to form groups } \\
\text { of seven students and } \\
\text { distributes the dialogue } \\
\text { prepared beforehand } \\
\text { and asks them to dis- } \\
\text { cuss the contents of the } \\
\text { dialogue with the par- } \\
\text { ticipation of the referee. }\end{array}$ & $\begin{array}{l}\text { The Students consti- } \\
\text { tute groups of seven } \\
\text { persons, the referee } \\
\text { distributes the text } \\
\text { of the dialogue, they } \\
\text { choose their roles, the } \\
\text { dialogues are read and } \\
\text { their contents are dis- } \\
\text { cussed. }\end{array}$ & $\begin{array}{l}\text { Group } \\
\text { work }\end{array}$ & $\begin{array}{l}\text { Dia- } \\
\text { logue } \\
\text { text }\end{array}$ \\
\hline 05 & $\begin{array}{c}10 \\
\text { min. }\end{array}$ & $\begin{array}{l}\text { The teacher asks the } \\
\text { students to take their } \\
\text { places in the class and } \\
\text { asks them to share the } \\
\text { ideas related to the } \\
\text { dialogue. }\end{array}$ & $\begin{array}{l}\text { The students take their } \\
\text { places in the classroom } \\
\text { and share the ideas } \\
\text { they have made. }\end{array}$ & Class & $\begin{array}{l}\text { Indi- } \\
\text { vidual } \\
\text { notes }\end{array}$ \\
\hline 06 & $\begin{array}{l}20 \\
\text { min. }\end{array}$ & $\begin{array}{l}\text { The teacher announces } \\
\text { that he will be playing } \\
\text { the professions card } \\
\text { game. He asks the stu- } \\
\text { dents to form groups } \\
\text { of five and distributes } \\
\text { the materials prepared } \\
\text { beforehand. }\end{array}$ & $\begin{array}{l}\text { The students thank the } \\
\text { teacher for the game } \\
\text { and form groups of } \\
\text { five. The game takes } \\
\text { place with the distribu- } \\
\text { tion of materials. After } \\
\text { the game the students } \\
\text { share the results of the } \\
\text { group studies with the } \\
\text { other students. }\end{array}$ & $\begin{array}{l}\text { Group } \\
\text { work } \\
\text { and } \\
\text { presen- } \\
\text { tation }\end{array}$ & $\begin{array}{l}\text { Materi- } \\
\text { als of } \\
\text { profes- } \\
\text { sions } \\
\text { card } \\
\text { game }\end{array}$ \\
\hline
\end{tabular}




\begin{tabular}{|c|c|c|c|c|c|}
\hline 07 & $\begin{array}{c}10 \\
\text { min. }\end{array}$ & $\begin{array}{l}\text { The teacher asks the } \\
\text { students to form groups } \\
\text { of five and distributes } \\
\text { the texts written on } \\
\text { "Professions". } \\
\text { He asks the students } \\
\text { to create a word list } \\
\text { (German and Turkish) } \\
\text { with nouns, adjectives } \\
\text { and verbs. He asks the } \\
\text { students to answer the } \\
\text { questions related with } \\
\text { the text at home. }\end{array}$ & $\begin{array}{l}\text { The students form } \\
\text { groups of five and } \\
\text { examine the texts dis- } \\
\text { tributed. } \\
\text { They create a word list } \\
\text { (German and Turkish) } \\
\text { with nouns, adjectives } \\
\text { and verbs. The stu- } \\
\text { dents write down the } \\
\text { homework.. }\end{array}$ & $\begin{array}{l}\text { Group } \\
\text { work }\end{array}$ & $\begin{array}{l}\text { Read- } \\
\text { ing text } \\
\text { answer } \\
\text { sheet }\end{array}$ \\
\hline 08 & $\begin{array}{c}6 \\
\min .\end{array}$ & $\begin{array}{l}\text { According to the sec- } \\
\text { ond section of the in- } \\
\text { structions the teacher } \\
\text { asks the flash cards, } \\
\text { clothespins and the } \\
\text { clothesline to be col- } \\
\text { lected and given to the } \\
\text { class leader. }\end{array}$ & $\begin{array}{l}\text { The students give the } \\
\text { flash cards, clothespins } \\
\text { and the clothesline to } \\
\text { the class leader. }\end{array}$ & $\begin{array}{l}\text { Indi- } \\
\text { vidual } \\
\text { work }\end{array}$ & $\begin{array}{l}25 \text { flash } \\
\text { cards, } \\
25\end{array}$ \\
\hline 09 & $\begin{array}{l}2 \\
\text { min. }\end{array}$ & $\begin{array}{l}\text { The teacher summariz- } \\
\text { es the activity, thanks } \\
\text { the participants and as- } \\
\text { signs them homework } \\
\text { for the next lesson. }\end{array}$ & $\begin{array}{l}\text { The students take notes } \\
\text { while listening to the } \\
\text { teacher. They thank the } \\
\text { teacher for the activity. }\end{array}$ & $\begin{array}{l}\text { Oral } \\
\text { state- } \\
\text { ment }\end{array}$ & \\
\hline \multicolumn{6}{|c|}{ Total period: 80 minutes } \\
\hline
\end{tabular}

Source: Author

Task: Create a trilingual (Turkish, German and English) word list from the reading text with nouns, verbs and adjectives. Present the word list of the class you have prepared. Share the work you prepared with the class.

\section{EVALUATION}

The evaluation of educational activities is important in lesson planning. The evaluation will be carried out to measure how close the planned objectives have been achieved (Bakırcıoğlu, 2016; Başol, 2016). The results of the evaluation provide feedback to the individual planning the teaching and learning process. Therefore, during the planning phase, the lesson to be assessed has to be planned in detail and the necessary measurement and assessment tools carefully prepared (Bayçu, Kocadağ \& Coşkun, 2014).

An observation and evaluation form consisting of ten questions has been developed for this lesson. The following is the observation and evaluation form for the subject professions created. 
OBSERVATION AND EVALUATION FORM

\begin{tabular}{ll}
\hline \multirow{2}{*}{ No } & \multicolumn{1}{c}{ Skills } \\
\cline { 2 - 2 } 01 & $\begin{array}{l}\text { Poor Passing Medium Good Excellent } \\
\text { participation in the theme of } \\
\text { the professions? }\end{array}$ \\
\hline 02 & $\begin{array}{l}\text { Was there sufficient discussion } \\
\text { on the subject by the participants } \\
\text { in the theme of the professions? }\end{array}$ \\
\hline 03 & $\begin{array}{l}\text { Were there any concrete } \\
\text { explanations on the topic of the } \\
\text { different professions? }\end{array}$ \\
\hline 04 & $\begin{array}{l}\text { Was the subject of professions } \\
\text { understood? }\end{array}$ \\
\hline 05 & $\begin{array}{l}\text { Were there discussions on the } \\
\text { models of professions? }\end{array}$ \\
\hline 06 & $\begin{array}{l}\text { Was the required information } \\
\text { about the professions delivered? }\end{array}$ \\
\hline 07 & $\begin{array}{l}\text { At the end of the lesson did } \\
\text { the participants establish a } \\
\text { connection between different } \\
\text { occupations? }\end{array}$ \\
\hline 08 & $\begin{array}{l}\text { Have different occupations } \\
\text { been discussed sufficiently? }\end{array}$ \\
\hline 09 & $\begin{array}{l}\text { Did you manage to draw the } \\
\text { attention of the participants to } \\
\text { the professions in class? }\end{array}$ \\
\hline 10 & $\begin{array}{l}\text { Was the expected productivity } \\
\text { of the class reached? }\end{array}$ \\
\hline
\end{tabular}

Source: Author

\section{CONCLUSION AND RECOMMENDATIONS}

At the beginning of this article, I emphasized that one of the purposes of the Turkish education system is to teach the youth to gain a profession. In spite of this, the majority of the students continue to attend schools that give academic education. Especially with the rise in the rate of unemployment among the graduates from academic schools, educational institutions and parents began to seek new avenues for employment. The book published by the Ministry of National Education titled "Happy Children Strong Turkey on the 2023 Education Forecast", widely discusses professional and technical education (training) (Selçuk, 2018).

Officials of the Ministry of Education state that professional and technical educations play a major role in the social and economic development of coun- 
tries. The measures to be taken in the Professional and technical education in the future are as stated below.

1. The $15 \%$ treasury deduction from the revolving funds of the secondary institutions which provide professional and technical education will be reduced to $1 \%$.

2. The curricula of the professional and technical education shall be flexible and will be prepared in a modular fashion.

3. While the education of the professional and technical education students continues the duration of stay in the actual working environment, it shall be increased through protocols for out of country technical training and the strategies will be varied according to the sectors.

4. Interim employees will be trained for the defense industry sector in which Turkey is highly competitive.

5. Microloans shall be given to the successful projects developed (produced) in the professional and technical training institutions.

6. In order to meet Turkey's requirements on qualified interim workers in Turkey's foreign trade, opportunities may be provided for professional and technical education abroad.

In order to fulfil the sixth opportunity, students attending professional schools should be fluent, at least, in one foreign language. Professional subjects should be taught in a foreign language. In one of the referenced articles, the teaching of a foreign language is also discussed. It is indicated that the "Game-Based Learning" approach has been adopted in the teaching of a foreign language in primary schools. In order to give the courses on professions in this approach, sample lesson plans should be prepared and the materials used in this sample lesson plans should be developed. I began my studies based on this concept on the subject of professions taking this approach as the basis. I prepared a list of words in three languages for the subjects specified at the beginning. Later, I designed repetitions for every subject. After my experiments in the class, I identified key words for every subject.

I have prepared a sample lesson plan for every subject for the last five years. One of these sample plans is included in this article. For the successful implementation of the sample lesson plan, I developed the necessary materials during and after the development of the lesson planning. From the information, I have compiled from my observation and evaluation forms it is noticed that the students show interest in subjects related to professions. The educational game I developed and the materials used in the implementation of the game allowed the lesson to be taught in a pleasant manner.

It was observed that students were interested in learning the German language, initially under the Erasmus program in countries where German is spoken, and later in Masters' programs and doctorates, likewise the students who wanted to go to Germany for a lengthy period of time to work there. I believe that these types of sample lessons will be beneficial. 


\section{RECOMMENDED SUBJECTS FOR THE EDUCATION OF PROFESSIONS}

The recommendations below are based on the experiences gained in the field of theory and application:

1. The necessary measure should be taken to direct the students in secondary schools to professional schools.

2. The quality of teaching a foreign language in professional schools should be improved.

3. Opportunities for out of country training abroad for the students attending professional schools should be researched for the students to improve their language skills.

4. Opportunities should be created for students to undergo training in foreign companies operating in Turkey. The initial proposal for this recommendation may be companies such as MAN, Bosch, Siemens, Mercedes.

5. The teachers working in professional schools should be fluent at least in one foreign language.

6. A sample lesson plan should be prepared for each profession.

7. Multi-language word lists should be prepared for each profession.

8. Materials that could be used in the sample lesson plans and that can improve four language skills should be prepared.

9. An educational game should be developed for each sample of education plan.

10. There should be a communication network among teachers who work in the field of professional education.

\section{REFERENCES}

[1] Aykır, Z. (2018). Mesleki ve Teknik Eğitimde Kullanılan Modüllerin Niteliğine İlişkin Öğrenci ve Öğretmen Görüşlerinin Değerlendirilmesi [Evaluation of Students and Teachers' views on the Quality of Modules Used in Vocational and Technical Education]. Yayınlanmamış yüksek lisans tezi (unpublished master's thesis). Ankara.

[2] Bakırcıoğlu, R. (2016). Ansiklopedik Eğitim ve Psikoloji Sözlüğü. [Encyclopedic Dictionary of Education and Psychology], Genişletilmiş 2. Ankara: Anı Yayıncılık.

[3] Başol, G. (2016). Eğitimde Ölçme ve Değerlendirme. [Measurement and Evaluation in Education]. Ankara: Pegem Akademi.

[4] Bayçu, S., Kocadağ, T. \& Coşkun, H. (2014). Masalların Dil Öğretiminde Kullanımı [Use of fairy tales in language teaching]. In: H. Coşkun (Ed.), Eğitim ve Öğretimde Masalların Önemi-Planlama, Uygulama ve Değerlendirme [The Importance of Fairy Tales in Education - Planning, Practising and Evaluating] (pp.15-32). Berlin: Dagyeli Verlag.

[5] Bayraktaroğlu, S. (2014). Neden Yabancı Dil Eğitiminde Başarılı Olamıyoruz? [Why can't we succeed in foreign language education?]. In: Arif Sarıçoban and Hüseyin Öz (Eds.). Türkiye'de Yabancı Dil Eğitiminde Eğilim Ne Olmalı? [Trends What Should Turkey in Foreign Language Education] (pp.1-7). Ankara: Hacettepe Yayınları.

[6] Bilen, M. (1993). Plandan Uygulamaya Öğretim [Plan to Practice ]. Ankara: TAKAV.

[7] Brandhofer-Bryan, K. (2008). Lernen mit allen Sinnen: 72 Sinn volle Lernspiele [Learning with all the senses: 72 Meaningful learning games]. Offenbach: Gabal Verlag. 
[8] Bundesagentur für, A. (2018). Beruf Aktuell-Lexikon der Ausbildungsberufe [Profession Current-Lexicon of Apprenticeships]. Ausgabe [Edition] 2018 / 2019. Nürnberg.

[9] Coşkun, H. (2006). Oyunlarla Dil Öğretimi, Spiele im Sprachunterricht. Learning Languages Through Games. Türkçe - İngilizce - Almanca. Ankara: CTB Yayınları.

[10] Coşkun, H., ve Deveci, T. (2006). Almanca Dil Bilgisi ve Testler [German Grammar and Tests]. Ankara: Siyasal kitabevi.

[11] Coşkun, H. (2013). The Importance of Educational Marble Games in Teaching German. Eurasian journal of Educational Research, 53, 151-174.

[12] Coşkun, H. (2018). Description of a Model for Lesson Planning on Peace Education in Teacher Training. Journal Education Culture Society, 1/2018, 118-142.

[13] Dinçer, Ö. (2012). Mesleki ve Teknik Eğitim Çalıștayında Yapılan Konuşma Metni [Text of Speech in Vocational and Technical Education Workshop]. In: Halis Yunus Ersöz \& Ömer Açıköz (Eds.). Mesleki ve Teknik Eğitim Çalıştayı [Vocational and Technical Education Workshop]. Mesleki ve Teknik Eğitim Genel Müdürlüğü: Manavgat. Antalya.

[14] E\&W Erziehung \& Wissenschaft, Zeitschrift der Bildungsgewerkschaft 10/2017. Individuelle Wertschätzung Berufliche Bildung [Education \& Science, Journal of the Education Union 10/2017. Individual Appreciation Vocational training]. Frankfurt: am Main.

[15] Glowacka-Perlowska, E. (2007). Einfach gut Deutsch für Alltag und Beruf, Band 1 [A subject good German for everyday life and occupation, Volume 1]. Bratislava: Fraus \& Goethe Institut Inter Nationes.

[16] Fearns, A., Buhlmann, R. (2013). Technisches Deutsch für Ausbildung und Beruf, Lehr- und Arbeitsbuch [Technical German for Education and Profession,Textbook and Workbook]. Europa Lehrmittel and Goethe - Institut: Haan-Gruiten.

[17] Häublein, G., Jenkins, R. (2018). Schlaumeier empfiehlt: Schul-Wortschatz Englisch komakt [Schlaumeier (wise guy) recommends: School vocabulary English compact]. Stuttgart: Ernst Klett Vertrieb.

[18] Hengirmen, M. (2006). Yabancı Dil Öğretim Yöntemleri ve TÖMER Yönteme [Foreign Language Teaching Methods and TÖMER Methodology]. Ankara: Engin Yayınevi.

[19] Hölscher, P., Piepho, H. E., Roche, J., Simic, M. (2006). Handlungsorientierter Unterricht mit Lernzenarien -Kernfragen zum Spracherwerb [Action-oriented teaching with learning scenarios-Core questions on language acquisition]. Oberursel: Finken Verlag.

[20] Kocaman, A. (2014). Yabancı Dil Öğretiminde Yöntem ve Ötesi [Foreign Language Teaching Method and Beyond]. In: Arif Sarıçoban \& Hüseyin Öz (Eds.), Türkiye'de Yabancı Dil Eğitiminde Eğilim Ne Olmalı? (pp.29-32). Ankara: Hacettepe Yayınları.

[21] Kocaman, A. (2018). İkinci Dil Öğrenimiyle İlgili Kimi Yaygin Görüşlerden Seçmeler [Selections from Some Common Opinions About Second Language Learning]. Öğreten Dünyası, Y1l. 39, Sayı 458, Şubat, 53-54.

[22] Koithan, U., Schgmitz, H., Sieber, T \& Sonntag, R. (2014). Aspekte neu Mittelstufe Deutsch Lehrbuch mit DVD B1 plus [Aspects new Intermediate German. Textbook with DVD B1 plus]. München: Klett-Langenscheid.

[23] Öz, H. (2014). Teknoloji ve Yabancı Dil Eğitimi [Technology and Foreign Language Education]. In: Arif Sarıçoban ve Hüseyin Öz (Ed.), Türkiye'de Yabancı Dil Eğitiminde Eğilim Ne Olmalı? (pp.167-176). Ankara: Hacettepe Yayınları.

[24] Republic of Turkey Ministry of National Education (2010). The Turkish Educational System. Ankara: MEB.

[25] Roche, J. (2005). Fremdsprachenerwerb Fremdsprachendidaktik. UTB basics. A. Francke Verlag: Tübingen und Basel.

[26] Selçuk, Z. (2018). Mutlu Çocuklar Güçlü Türkiye, 2023 Eğitim Vizyonu [Happy Children Strong Turkey on the 2023 Education Forecast]. Ankara: Milli Eğitim Bakanlığı.

[27] The Common European Framework of Reference for Languages (GER) Learning, Teaching, assessment (2011). Council of Europe, Modern Languages Division. Strasbourg: Cambridge University Press.

[28] Viau, R. (2009). La motivation à apprendre en milieu scolarire, Éditions du Renouveau Pédagogique Inc. Tous Droits Reservés [Motivation in school, learning motivation and motivation in school], translated by Yusuf Budak (2015). Ankara: Anı Yayıncllı. 
[29] Yıldırım, A., Şimşek, H. (2008). Sosyal bilimlerde nitel Araştırma yöntemleri [Qualitative research methods in social sciences]. Ankara: Seçkin Yayincilik.

[30] Yllmaz, E. (2011). Mein Sprach- und Deutschlandbegleiter: Konuşma ve Almanya Rehberim. München: Goethe-Institut.

[31] YÖK (2007). Öğretmen Yetiştirme ve Eğitim Fakülteleri [Teacher Training and Faculties of Education]. Yükseköğretim Kurulu (Higher Education). Ankara.

[32] Sosyal Bilgiler.gen.tr. (2008). Türk eğitim sisteminin genel amaçları. Retrieved December 20, 2018 from http://www.sosyalbilgiler.gen.tr/forum/yonetmelik-ve-genelgeler/ turk-egitim-sisteminin-genel-amaclari/.

\section{ILLUSTRATIONS}

00. Retrieved January 20, 2019 from https://www.bild.de/themen/specials/beruf/news-fotos-videos-17002374.bild.html.

01. [Untitled illustration of soldier]. Retrieved May 30, 2018 from https://tr.123rf.com/stok-foto\%C4\%9Fraf/asker.html?sti=mv0ykaxjbit1tmot46|\&mediapopup.

02. [Untitled illustration of gardener]. Retriever June 3, 2018 from https:// de.123rf.com/lizenfreie-bilder/g\%C3\%A4rtner.html?sti=nshxut6pcg5n8rfgj3 |\&mediapopup.

03. [Untitled illustration of bank employee]. Retrieved April 28, 2018 from https:/ / www.nasilolunur.com/bankaci-nasil-olunur/.

04. [Untitled illustration of garbage man]. Retrieved April 29, 2018 from https://de.fotolia.com/ $\mathrm{tag} / \mathrm{m} \% \mathrm{C} 3 \%$ BCllwerker.

05. [Untitled illustration of doctor]. Retrieved July 13, 2018 from https://pixabay.com/tr/ erkek-karikat\%C3\%BCr-check-up-klinik.

06. [Untitled illustration of photographer]. Retrieved July 15, 2018 from https:// pixabay.com/tr/ foto $\%$ C4\%9Fraf\%C3\%A7\%C4\%B1-kamera-beach-adam-deniz.

07. [Untitled illustration of football player]. Retrieved August 8, 2018 from http://www.thinkstockphotos.de/image/stock-foto-fu\%C3\%9Fballspieler-dribbeln/.

08. [Untitled illustration of waiter]. Retrieved August 10, 2018 from https://pixabay.com/tr/ insanlar- \%C3\%A7ift-garson-tablo.

09. [Untitled illustration of nurse]. Retrieved September 17, 2018 from https://tr.123rf.com/stokfoto $\%$ C4\%9Fraf/hem\%C5\%9Fire.html?sti=nqajgh3nwv3ubx7b17|\&mediapopup.

10. [Untitled illustration of sculptor] http://www.animierte-gifs.net/img-animiertes-bildhauer-bild-0006-172645.htm.

11. [Untitled illustration of construction worker]. Retriever September 30, 2018 from http:// www.gratis-malvorlagen.com/gratis-malvorlagen-von-bauarbeiter-zum-ausdrucken/ gratis-malvorlagen-bauarbeiter-1/.

12. [Untitled illustration of cameraman]. Retriever August 16, 2018 from https:// pixabay.com/tr/ kameraman- filmler-video-film-309112/.

13. [Untitled illustration of captain]. Retrieved December 13, 2018 from https://de.123rf.com/ lizenzfreie-bilder/seemann.html?sti=nvq38uavzu3e4r153d | \&mediapopup.

14 [Unttitled illustration of carpenter]. Retrieved December 19, 2018 from https://www.clipartsfree.de/clipart-bilder-galerie/ berufe-bilder-clipart-free/tischler-clipart-bild-cartoon-grafik-5967.html.

15. [Untitled illustration of architect]. Retrieved January 17, 2018 from http://www.magusa.org/ arsiv/haber2_08.htm.

16. [Untitled illustration of engineer]. Retrieved January 18, 2018 from https://de.freepik.com/ fotos-vektoren-kostenlos/ingenieur.

17. [Untitled illustration of musician]. Retrieved February 1, 2018 from https://pixabay.com/ tr/\%C3\%A7ello-alet-m\%C3\%BCzisyen-\%C3\%A7ellist-m\%C3\%BCzik.

18. [Untitled illustration of teacher]. Retrieved February 12, 2018 from https://pixabay.com/ tr/\%C3\%B6\%C4\%9Fretmen-parmak-insanlar-adam.

19. [Untitled illustration of pilot]. Retrieved May 31, 2018 from https:/ /www.1001freedownloads. $\mathrm{com} /$ free-clipart/ pilot-2.

20. [Untitled illustration of painter]. Retrieved March 16, 2018 from https://pixabay.com/tr/ el-boyama-\%C3\%A7izim-ressam. 
Journal of Education Culture and Society No. 1_2019

21. [Untitled illustration of secretary]. Retrieved March 18, 2018 from http://www.supercoloring. $\mathrm{com} /$ it/disegni-da-colorare/centralinista?version=print.

22. [Untitled illustration of driver]. Retrieved , November 6, 2018 from https:/ / www.clipartsfree de/clipart-bilder-galerie/berufe-bilder-clipart-free/ formel-1-fahrer-rennfahrer-clipart-bild-kostenlos-1102.html.

23. [Untitled illustration of repairman]. Retrieved November 8, 2018 from https:// pixabay.com/ tr/tesisat\%C3\%A7\%C4\%B1-onar\%C4\%B1m-mekanik.

24. [Untitled illustration of tailor]. Retrieved October 2, 2018 from http://clipart-library.com/clipart/111217.htm.

ANNEX 1

\begin{tabular}{|c|c|c|c|}
\hline Nr. & $\begin{array}{l}\text { Resim/Bild / } \\
\text { Picture }\end{array}$ & $\begin{array}{l}\text { Sözcük/Wort / } \\
\text { Word }\end{array}$ & Cümle / Satz / Sentence \\
\hline \multirow{3}{*}{01} & \multirow{3}{*}{ 逭 } & Asker & \\
\hline & & der Soldat & $\begin{array}{l}\text { Der Soldat erzählt über seine } \\
\text { Erlebnisse im Krieg. }\end{array}$ \\
\hline & & Soldier & \\
\hline \multirow{3}{*}{02} & & \multicolumn{2}{|l|}{ Bahçıvan } \\
\hline & & der Gärtner & $\begin{array}{l}\text { Der Gärtner pflanzt heute im Garten } \\
\text { Blumen. }\end{array}$ \\
\hline & & \multicolumn{2}{|l|}{ Gardener } \\
\hline \multirow{3}{*}{03} & & \multicolumn{2}{|l|}{ Banker } \\
\hline & & der Bankier & $\begin{array}{l}\text { Der Bankier arbeitet im Vorstand einer } \\
\text { großen Bank. }\end{array}$ \\
\hline & & Banker & \\
\hline \multirow{3}{*}{04} & & \multicolumn{2}{|l|}{ Çöpçü } \\
\hline & & der Müllmann & $\begin{array}{l}\text { Der Müllmann leert um } 08.00 \text { Uhr die } \\
\text { Tonnen aus. }\end{array}$ \\
\hline & & Garbage man & \\
\hline \multirow{3}{*}{05} & & \multicolumn{2}{|l|}{ Doktor } \\
\hline & & der Doktor & $\begin{array}{l}\text { Der Doktor untersucht jeden Tag } 20 \\
\text { Patienten. }\end{array}$ \\
\hline & & Doctor & \\
\hline \multirow{3}{*}{06} & & \multicolumn{2}{|l|}{ Fotoğrafçı } \\
\hline & & der Fotograf & $\begin{array}{l}\text { Der Fotograf fotografiert eine Familie } \\
\text { in Afrika. }\end{array}$ \\
\hline & & Photographer & \\
\hline \multirow{3}{*}{07} & \multirow{3}{*}{ ris. } & Futbolcu & \\
\hline & & der Fußballspieler & $\begin{array}{l}\text { Der deutsche Fußballspieler spielt in } \\
\text { der Türkei. }\end{array}$ \\
\hline & & Football player & \\
\hline
\end{tabular}




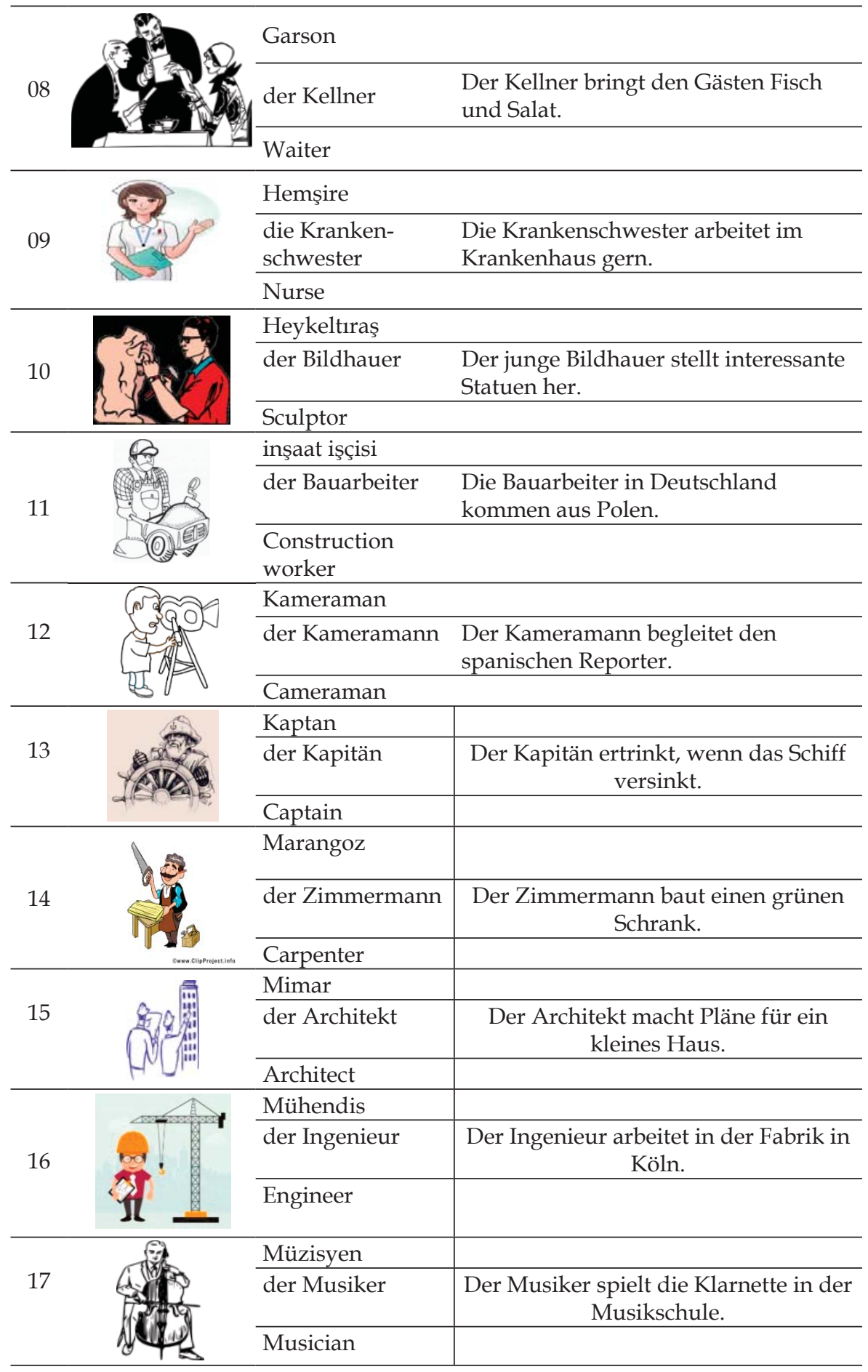




\begin{tabular}{|c|c|c|}
\hline \multirow{3}{*}{18} & Öğretmen & \\
\hline & der Lehrer & $\begin{array}{c}\text { Der Lehrer unterrichtet Englisch und } \\
\text { Deutsch. }\end{array}$ \\
\hline & Teacher & \\
\hline \multirow{3}{*}{19} & Pilot & \\
\hline & der Pilot & $\begin{array}{l}\text { Der Pilot fliegt mit dem Flugzeug nach } \\
\text { Berlin. }\end{array}$ \\
\hline & Pilot & \\
\hline \multirow{3}{*}{20} & Ressam & \\
\hline & der Maler & $\begin{array}{l}\text { Der Maler arbeitet mit Farben und } \\
\text { Pinseln. }\end{array}$ \\
\hline & Painter & \\
\hline \multirow{3}{*}{21} & Sekreter & \\
\hline & die Sekretärin & $\begin{array}{l}\text { Die Sekretärin schreibt für ihren Chef } \\
\text { Briefe. }\end{array}$ \\
\hline & Secretary & \\
\hline \multirow{3}{*}{22} & Şoför & \\
\hline & der Fahrer & $\begin{array}{l}\text { Der Fahrer kommt jeden Tag mit } \\
\text { einem Bus. }\end{array}$ \\
\hline & Driver & \\
\hline \multirow{3}{*}{23} & Tamirci & \\
\hline & der Mechaniker & $\begin{array}{c}\text { Der Mechaniker repariert eine alte } \\
\text { Maschine. }\end{array}$ \\
\hline & Repairman & \\
\hline \multirow{3}{*}{24} & Terzi & \\
\hline & der Schneider & $\begin{array}{l}\text { Der Schneider kauft für einen Anzug } \\
\text { grünen Stoff. }\end{array}$ \\
\hline & Tailor & \\
\hline
\end{tabular}

Source: Author 2

ANNEX 2

01 am Montag / Der Soldat erzählt / über seine / im Krieg / Erlebnisse / .

02 heute / Der Gärtner / im Garten / pflanzt / schöne Blumen / .

03 arbeitet / Der Bankier / dieses Jahr / einer großen Bank / im Vorstand / .

$04 \quad$ Der Müllmann / um 08.00 Uhr / Tonnen aus / leert / . / die vollen

05 Der / Doktor untersucht / 20 Patienten / . / junge / jeden Tag 
06 fotografiert / Der Fotograf / am Dienstag / in Afrika / . / eine Familie

$07 \quad$ Fußballspieler / Der deutsche / spielt / in der Türkei / . / diese Woche

08 Der Kellner / am Mittwoch / Fisch und Salat / . / bringt / den Gästen

09 Die / arbeitet / im Krankenhaus / immer / gern / . / Krankenschwester

10 Der / Bildhauer stellt / jeden Monat / her. / interessante Statuen / junge

11 im Sommer / Die Bauarbeiter in Deutschland / aus Polen / sind / gekommen.

12 begleitet / Der Kameramann / am Donnerstag / Reporter / den spanischen/

13 Der Kapitän / wenn das Schiff / ertrinkt, / in einer Stunde / versinkt / .

14 baut / Der Zimmermann / am Freitag / Schrank / einen grünen.

15 Der Architekt / am Samstag / für ein kleines Haus. / Pläne / macht

16 arbeitet / Der Ingenieur / seit zwei Jahren / in Köln. / in der Fabrik

17 spielt / Der Musiker / am Sonntag / in der Musikschule. / die Klarnette

18 unterrichtet / Der Lehrer / im Frühling / und Deutsch / Englisch / .

19 fliegt / Der Pilot / gleich / nach Berlin. / mit dem Flugzeug

20 Der / arbeitet / Maler / und Pinseln / . / immer mit Farben

21 schreibt / Die Sekretärin / oft für ihren / Briefe / Chef / .

22 Der Fahrer / mit einem Bus / jeden Tag / . / kommt

23 im Winter / Der Mechaniker / repariert / Maschine. / eine alte

24 Der Schneider / im Herbst / kauft / grünen Stoff / für einen Anzug / .

Vor- und Nachnamen: ................ Listen-Nummern:.... Gruppe: A Datum: .... (Partnerarbeit)

Verilen sözcüklerle cümleler yazınız. Schreiben Sie mit den vorgegebenen Wörtern Sätze. 
Journal of Education Culture and Society No. 1_2019

Write sentences using the given words.

01 Der Soldat erzählt am Montag über seine Erlebnisse im Krieg.

02 Der Gärtner pflanzt heute im Garten schöne Blumen.

03 Der Bankier arbeitet dieses Jahr im Vorstand einer großen Bank.

$04 \quad$ Der Müllmann leert um 08.00 Uhr die vollen Tonnen aus.

05 Der junge Doktor untersucht jeden Tag 20 Patienten.

06 Der Fotograf fotografiert am Dienstag eine Familie in Afrika.

07 Der deutsche Fußballspieler spielt diese Woche in der Türkei.

$08 \quad$ Der Kellner bringt am Mittwoch den Gästen Fisch und Salat.

09 Die Krankenschwester arbeitet immer im Krankenhaus gern.

10 Der junge Bildhauer stellt jeden Monat interessante Statuen her.

11 Die Bauarbeiter in Deutschland sind im Sommer aus Polen gekommen

12 Der Kameramann begleitet am Donnerstag den spanischen Reporter.

13 Der Kapitän ertrinkt, wenn das Schiff in einer Stunde versinkt.

14 Der Zimmermann baut am Freitag einen grünen Schrank.

15 Der Architekt macht am Samstag Pläne für ein kleines Haus.

16 Der Ingenieur arbeitet seit zwei Jahren in der Fabrik in Köln.

17 Der Musiker spielt am Sonntag die Klarnette in der Musikschule.

18 Der Lehrer unterrichtet im Frühling Englisch und Deutsch.

19 Der Pilot fliegt gleich mit dem Flugzeug nach Berlin.

20 Der Maler arbeitet immer mit Farben und Pinseln.

21 Die Sekretärin schreibt oft für ihren Chef Briefe.

22 Der Fahrer kommt jeden Tag mit einem Bus.

23 Der Mechaniker repariert im Winter eine alte Maschine.

24 Der Schneider kauft im Herbst für einen Anzug grünen Stoff.

Source: Bayçu, S., Kocadağ, T., Coşkun, H. (2014). Masalların Dil Öğretiminde Kullanımı, yer aldığı eser. In: H. Coșkun (Ed.), Eğitim ve Öğretimde Masalların Önemi - Planlama, Uygulama ve Değerlendirme / The Importance of Fairy Tales in Education - Planning, Practising and Evaluating. Berlin: Dagyeli Verlag. 